AbStRACt: The FUll Version WAS PUblished in THE JoURnal of the AMERICAN ACADEMY OF RELIGION.

https://academic.oup.com/jaar/article-abstract/doi/10.1093/jaarel/IfxO26/3940210/Derrida-and-theDanger-of-Religion

Feel free to message the author if you would like the full text of the article.

$\infty$

\title{
DERRIDA AND THE DANGER OF RELIGION
}

- David Newheiser -

\begin{abstract}
This paper argues that Jacques Derrida provides a compelling rebuttal to a secularism that seeks to exclude religion from the public sphere. Political theorists such as Mark Lilla claim that religion is a source of violence, and so they conclude that religion and politics should be strictly separated. In my reading, Derrida's work entails that a secularism of this kind is both impossible (because religion remains influential in the wake of secularization) and unnecessary (because religious traditions are diverse and multivalent). Some attempt to contain the disruptive force of religion by excluding it from the public sphere, but Derrida argues that one may endure instability for the sake of something more important than safety. Although Derrida admits that religion is dangerous, he demonstrates that it is nevertheless an indispensable resource for political reflection.
\end{abstract}

